\section{Dental study tours}

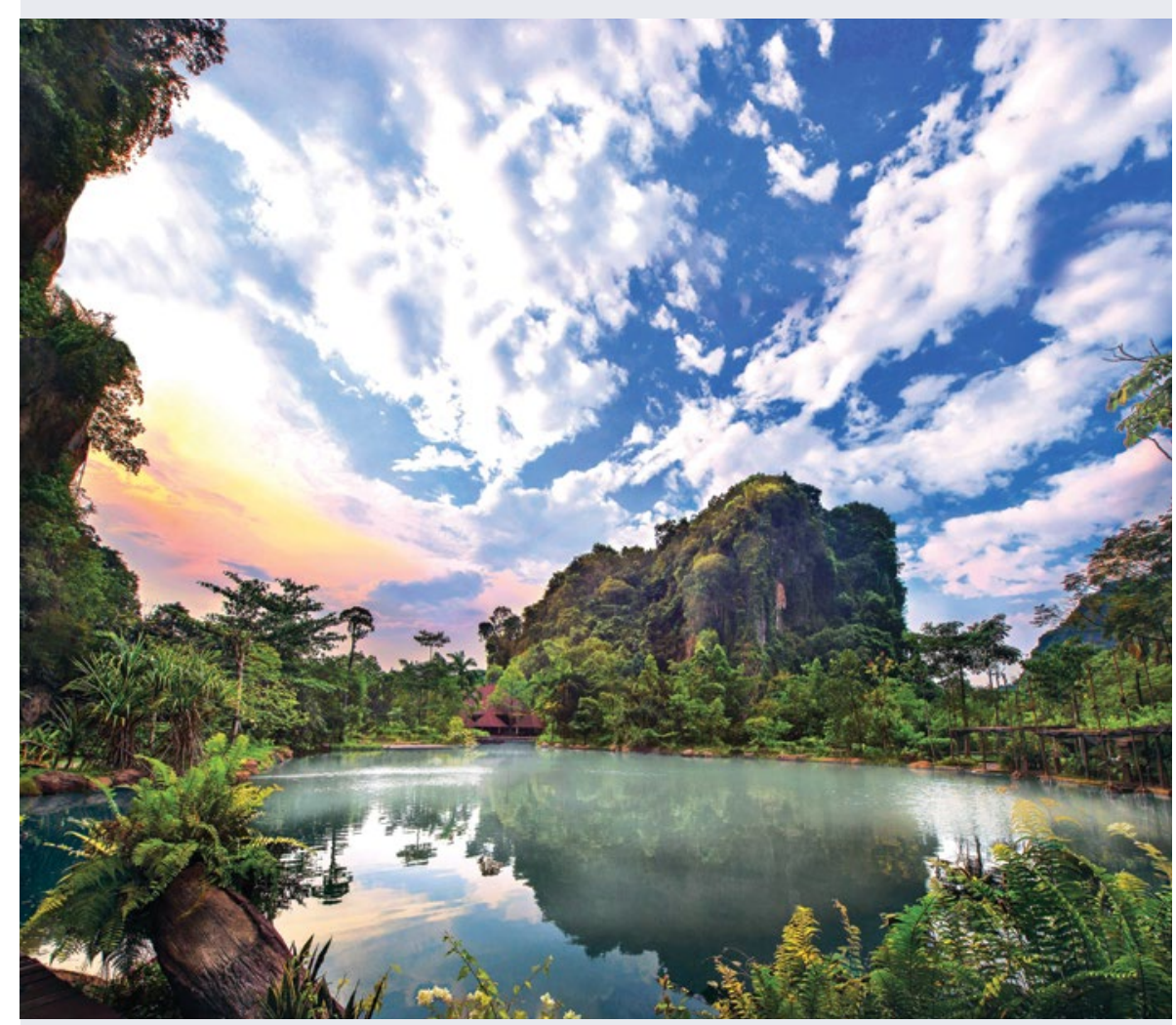

Dental cruise in the Baltic, 14-23 September 2020

Cruise through some of the most beautiful parts of the Baltic and explore destinations steeped in history, art and culture. Start in Copenhagen, the picturesque capital of Denmark with its canals and cobbled streets and sail to Warnermunde to explore this pretty German seaside town and visit the historic medieval city of Rostock, home to Germany's oldest university. Explore the beautiful city of Tallinn, with its winding medieval streets, and Toompea Castle. Continue to St Petersburg and explore the magnificent city founded by the Russian tsar, Peter the Great. Optional excursions include the Hermitage or the beautiful palace of Catherine the Great or a cruise along the Neva River. Helsinki is the next port of call, a city defined by its people and Art Nouveau architecture. Continue onto Stockholm to visit the Nobel Hall and learn about the Vikings. The cruise ends back in Copenhagen.

The cruise includes dental lectures by tour leader Dr Derek Mahoney and ample time to relax on board the NCL ship Norwegian Getaway.
Full details are at www.jonbainestours. com/baltic.

\section{Borneo and the Malay Peninsula, 4-17 May 2020}

From the vast jungles of Borneo and the riverine city of Kuching, travel with Jon Baines Tours to the Malay Peninsula, the modern city of Kuala Lumpur and the historic state, Malacca. Travel by boat into the world's oldest rainforest in Taman Negara and onto the Cameron Highlands, with its colonial hill stations and tea estates. Spend the night in a luxury natural spa resort surrounded by jungle clad mountains. Take the train and ferry to George Town, a UNESCO World Heritage site with striking architecture and a rich cultural legacy. Along the way enjoy the blend of European heritage with Malay, Chinese and Indian culture and cuisine. Wander through rainforest trails and street-food markets and take in the sights, sounds, smells and flavours of a truly diverse country.

This tour led by Kevin Esplin combines a full dental professional programme with a richly rewarding cultural experience.

Full details are at www.jonbainestours. com/dental.

\section{Lightning-fast setting prowess}

3M Oral Care made a big impact at this year's BDIA Dental Showcase.

Impressing crowds of delegates that gathered at its stand, $3 \mathrm{M}$ presented one of its most recent innovations - Filtek Universal restorative. The new, stress-free way to restore, Filtek Universal restorative from $3 \mathrm{M}$ offers a simplified shade selection and new shades for complex conditions - Extra White (XW) for bleached teeth and Pink Opaquer to mask metal or treat stained dentition.

$3 \mathrm{M}$ also showed off the lightningfast setting prowess of its Impregum Super Quick polyether impression material. Faster, better tasting and versatile to clinicians' needs, Impregum Super Quick combines the speed of a VPS with the world-famous accuracy of Polyether.

If you missed 3M Oral Care at the BDIA Showcase, be sure to contact the team today to learn more.

For more information, call 01509 380090 or visit www.3M.co.uk/Dental.

$3 \mathrm{M}$, Filtek and Impregum are trademarks of the $3 \mathrm{M}$ Company.

\section{Expert advice on magnification and illumination equipment}

Nuview put on an impressive display of Carl Zeiss solutions at BDIA Dental Showcase 2019. The team engaged with interested delegates through on-stand demonstrations, where Nuview's expert advice was sought on the range of magnification and illumination equipment on offer.

This included the revolutionary EXTARO 300 dental microscope with breakthrough visualisation modes that introduce new applications to micro-dentistry. In addition, delegates were able to put the EyeMag Pro and EyeMag Smart dental loupes to the test.

Those seeking a reliable alternative to alcohol disinfectants also benefitted from demonstration of Nuview's Continu alcoholfree products.

For more information call Nuview on 01453 872266, email info@nuview-ltd.com, visit www.nuview.co or 'like' Nuview on Facebook. 